\title{
Isolation, identification and biocontrol potential of entomopathogenic nematodes occurring in Purvanchal and Bundelkhand regions of Uttar Pradesh, India
}

Manjunatha T. Gowda* ${ }^{*}$, Jagadeesh Patil ${ }^{2}$, Vijayakumar R. ${ }^{2}$, Jaydeep Halder ${ }^{1}$, Veereshkumar ${ }^{2}$, Pratap A. Divekar ${ }^{1}$, A. B. Rai ${ }^{1}$ and Jagdish Singh ${ }^{1}$

\begin{abstract}
Entomopathogenic nematodes (EPNs) are being used for the management of insect pests occurring in both agricultural and horticultural crops. But native EPNs are reasonably more efficacious in controlling insect pests than introduced EPNs species because they are adapted to local environmental conditions and insect pests. Therefore, in the present study, a survey was conducted to isolate EPNs at 4 districts of Purvanchal Region and 1 district of Bundelkhand Region of Uttar Pradesh, India, between 2016 and 2017 years. Out of 130 soil samples, EPNs were recovered from 3 soil samples (2.3\%). Morphological characters examination and ITS-rDNA region revealed that the 3 EPNs such as Steinernema sp. (IIVR JNC01 strain) Steinernema sp. (IIVR JNC02 strain), and Steinernema sp. (IIVR EPN03 strain) are belonging to Steinernema siamkayai. Further pathogenicity of all these strains was tested on Galleria mellonella Linnaeus and the most effective strain was used to determine the biocontrol potential against lepidopteran and coleopteran pests of major vegetable crops in comparison to commercially available Heterorhabditis indica (NBAllH38 strain). Results revealed that S. siamkayai (IIVR JNC01 strain) caused 100, 100, and $85 \%$, mortality of $3^{\text {rd }}$ instar larvae of Spodoptera litura Fabricius, Spilosoma obliqua Walker, and Spoladea recurvalis Fabricius, respectively. Similarly, S. siamkayai (IIVR JNC01 strain) caused $92.5 \%$ mortality of $2^{\text {nd }}$ instar grubs of Myllocerus subfaciatus Gurein under laboratory conditions. The present study revealed that EPNs commonly present at Purvanchal and Bundelkhand regions of Uttar Pradesh and S. siamkayai (IIVR JNC01 strain) isolated from the Bundelkhand Region showed a good biocontrol potential against major insect pests of vegetable crops.
\end{abstract}

Keywords: Entomopathogenic nematodes, Isolation, Molecular characterization, Biological control, India

\section{Background}

With the rapid development and advancement of synthetic chemistry in the early decades of twentieth century, a range of new chemical insecticides had been developed. These chemical insecticides are being used to control insect pests occurring in both agricultural and horticultural crops. However, indiscriminate use of chemical insecticides leads to resistance in insect pest population and non-target

\footnotetext{
*Correspondence: goudru9@gmail.com

${ }^{1}$ ICAR-Indian Institute of Vegetable Research, Varanasi 221305, India

Full list of author information is available at the end of the article
}

effects. Therefore, search of alternative methods to scale down the use of chemical insecticides is gaining importance (Bohinc et al. 2019). Biological control program is one of the alternative methods to chemical insecticides. It exploits insects, bacteria, viruses, fungi, and entomopathogenic nematodes (EPNs). Among these biocontrol agents, EPNs are lethal obligate parasites belonging to Steinernematidae and Heterorhabditidae families (Ishibashi and Choi 1991). They are mutually associated with gram-negative bacteria Xenorhabdus spp. and Photorhabdus spp., respectively, and kill infected insect host within $24-48 \mathrm{~h}$ by causing 
septicemia (Ciche et al. 2006). These nematodes naturally occur in soil and epigeal habitats, and have been isolated from most regions of the world (Kaya and Gaugler 1993). Many laboratory and field studies have indicated that EPNs have potential to control insect pests of vegetable crops (Park et al. 2001; Somvanshi et al. 2006; Trdan et al. 2007; Laznik et al. 2011; Ebssa and Koppenhofer 2011 and Gowda et al. 2016). However, for the effective management of insect pests, native EPN species/strains play a major role because they are easily adapted to local climatic conditions and insect pests (Gaugler 1988 and Noosidum et al. 2010).

Occurrence and distribution of EPNs have been studied in some isolated parts of Uttar Pradesh (Istkhar and Chaubey 2017 and Devindrappa et al. 2019). However, occurrence and distribution of EPNs in Purvanchal and Bundelkhand regions of Uttar Pradesh, India, are previously unexplored.

In this connection, the present study is designed to isolate, identify, and characterize the native EPNs from Purvanchal and Bundelkhand regions of Uttar Pradesh, India, and also to evaluate their biocontrol potential against major lepidopteran and coleopteran pests of major vegetable crops grown in these regions.

\section{Material and methods}

\section{Insect culture}

Greater wax moth, Galleria mellonella Linnaeus, was reared on artificial diet according to the method (Patil et al. 2020). The last larval instars of G. mellonella were used for the experiment.

Biocontrol potential of EPNs was tested against Spodoptera litura Fabricius infesting cabbage Brassica oleracea var. capitata, Spilosoma obliqua Walker on brinjal, Solanum melongena Linnaeus, and Spoladea recurvalis Fabricius on amaranthus, Amaranthus tricolor Linnaeus in this study. A continuous culture of these insect hosts was maintained in an insectary at $26 \pm 2{ }^{\circ} \mathrm{C}$ and $70 \pm 5 \% \mathrm{RH}$, a photo phase of $14 \mathrm{~h}$ and scoto phase of $10 \mathrm{~h}$. For initial establishment of the culture, different larval stages of these insects were collected from their respective host plants grown in research farm of ICAR- Indian Institute of Vegetable Research, Varanasi $\left(25^{\circ} 10^{\prime} 55.6^{\prime \prime} \mathrm{N}, 82^{\circ} 52^{\prime} 37.2^{\prime \prime}\right.$ E; $80.71 \mathrm{~m}$ above sea level), Uttar Pradesh, India. The larvae were individually reared on their natural diet viz., S. litura on cabbage, S. obliqua on brinjal, and S. recurvalis on amaranthus in Petri dish (diam. $9 \mathrm{~cm}$, depth $1.8 \mathrm{~cm}$ ). Third instar larvae of these insect species were used for the bioassays.

Second instar grubs of Myllocerus subfaciatus Gurein were collected from naturally infested eggplants grown in ICAR-NBAIR research farm, Bengaluru (13 $05^{\prime} 48.7^{\prime \prime} \mathrm{N}$, $77^{\circ} 34^{\prime} 02.8^{\prime \prime}$ E; $920 \mathrm{~m}$ above sea level), Karnataka, India. Grubs were kept in $100 \mathrm{ml}$ plastic containers (diam. 5.8 $\mathrm{cm}$, height $8 \mathrm{~cm}$, soil capacity $115 \mathrm{~g}$, total surface area $198.61 \mathrm{~cm}^{2}$, shape; round) containing $100 \mathrm{~g}$ of autoclaved soil with $12 \%$ moisture for 2 days at $25 \pm 1{ }^{\circ} \mathrm{C}$. Potato (Solanum tuberosum L.) pieces were provided to feed the grub. Three days after apparently healthy grubs were used for bioassay.

\section{Isolation of native EPNs}

In the present study, a survey was conducted during 2016 and 2017 in four districts of Purvanchal Region, i.e., Varanasi, Mirzapur, Sonbhadra, Deoria, and one district at Bundelkhand Region, i.e., Jhansi of Uttar Pradesh; these areas were previously unexplored. Soil samples were collected randomly using hand shovel from agricultural, horticultural, and forest ecosystems from early $\mathrm{Au}$ gust to late November. In total, 130 soil samples were collected. Each representative sample (approximately 1 $\mathrm{kg}$ each) consists of 5 soil samples were taken at a depth of $15-20 \mathrm{~cm}$. Then, soil samples were placed in polythene bags and transferred to the laboratory for investigation (Yuksel and Canhilal 2019). To isolate EPNs from the soil samples, soils were placed in $1000 \mathrm{ml}$ plastic container (diam. $10.5 \mathrm{~cm}$, height $14.5 \mathrm{~cm}$, soil capacity $1100 \mathrm{~g}$, total surface area $731.59 \mathrm{~cm}^{2}$, shape is round) with 4 individuals of last instar G. mellonella larvae. The plastic containers were covered with a lid having a small pin holes for allowing air flow, then containers were incubated at $25 \pm 1{ }^{\circ} \mathrm{C}$ for 1 week. Soil samples were checked on a daily basis for 7 days to observe the cadavers of the larvae of G. mellonella. All recovered dead larvae of Galleria were placed individually on White's traps (White 1927). Infective juveniles (IJs) emerged from these dead larvae were collected and stored at $15{ }^{\circ} \mathrm{C}$. Two- to 3-day-old IJs of each nematode strain was tested against 20 individuals of the last instar G. mellonella larvae to confirm Koch's postulates for pathogenicity (Pelczar and Reid 1972 and Kaya and Stock 1997).

\section{Morphology and morphometry of native EPN strains}

To study the morphology and morphometrics of EPNs strains, last instar larvae of Galleria were inoculated at rate of $200 \mathrm{IJs}_{\text {larva }}{ }^{-1}$ and incubated $25 \pm 1{ }^{\circ} \mathrm{C}$ in the dark. Three days after larval death, first generation adults were collected by dissecting the cadavers in Ringer's solution. Similarly, second generation adults were collected $5^{\text {th }}$ day after larval death. Infective juveniles were harvested from cadavers of the larvae of $G$. mellonella with the help of White's traps. The adults of both generations and IJs were killed by pouring hot fixative and then fixed in TAF and processed, using Seinhorst I and Seinhorst II reagents (Seinhorst, 1959). The adults of both generations and IJs were mounted in dehydrated glycerin, using appropriate sized glass support. The mounted specimens were used for detailed microscopic studies (Poinar 1990). The measurements 
and examination of morphology were completed, using Trinocular Research Microscope (model Axio Imager Z2 by Carl Zeiss Microscopy $\mathrm{GmbH}$ provided with DIC optics) with suitable photomicrographs. For each Steinernema IIVR strain, 20 specimens of each developmental stage were examined. The results of morphometric and morphological characters of EPN strains isolated in this study were compared to the original description of S. siamkayai Stock, Somsook, and Reid.

\section{Molecular characterization of native EPN strains}

The genomic DNA was extracted from a single female of each Steinernema IIVR strain, using a modified method of Joyce et al. (1994). The ITS region of the EPN strains DNA was amplified by polymerase chain reaction (PCR) mixture containing $10 \mu \mathrm{l}$ of the DNA suspension, $2.5 \mu \mathrm{l}$ 10× PCR buffer with $\mathrm{MgCl}_{2}, 0.5 \mu \mathrm{l}$ dNTP mixture (10 $\mathrm{mM}$ each), $0.5 \mu \mathrm{l}(100 \mathrm{pM} / \mu \mathrm{l})$ of each primer, 0.3U Taq polymerase, and $10.7 \mu \mathrm{l}$ double distilled water to make volume of $25 \mu \mathrm{l}$. The forward primer TW81 (5'-GTTTCC GTAGGTGAACCTGC- $3^{\prime}$ ) and the reverse primer AB28 (5'-ATATGCTTAAGTTCAGCGGGT-3') were used in the PCR reaction for amplification of the complete ITS. The amplified PCR products were purified using a Qiagen Gel Purification Kit. The fragments of DNA were sequenced by Sanger's method (Eurofins Genomics India Pvt., Ltd., Bengaluru, India). Sequences of the ITS-rDNA region of the EPN were used to study the phylogenetic relationships between the Steinernema IIVR strains and other related 21 Steinernema species, and Caenorhabditis elegans was used as an out group. The DNA sequences were edited using BioEdit with sequences of related species/strains. The accession numbers are cited in the phylogenetic tree were obtained from in GenBank by means of a BLAST tool of the NCBI. The phylogenetic analysis of sequence data were performed based on their ITSrDNA region through Neighbor Joining method using MEGA 7.0 (Kumar et al. 2016).

\section{Source of nematodes for laboratory bioassays}

Entomopathogenic nematode species/strains such as Steinernema sp. (IIVR JNC01 strain), Steinernema sp. (IIVR JNC02 strain), Steinernema sp. (IIVR EPN03 strain), and Heterorhabditis indica (NBAIIH38 strain) were cultured in last instar larvae of G. mellonella (Kaya and Stock 1997). Two to 3-day-old IJs were used for laboratory bioassays. Virulence of all three Steinernema spp. IIVR strains was tested on last instar larvae of G. mellonella. Based on the better virulence, Steinernema sp. (IIVR JNC01 strain) was selected to test the biocontrol potential against lepidopteran and coleopteran pests in comparison to commercially available $H$. indica (NBAIIH38 strain).

\section{Evaluation of biocontrol potential against lepidopteran pests of vegetable crops}

In this study, Steinernema sp. (IIVR JNC01 strain) was tested against $S$. litura, S. obliqua and $S$. recurvalis in comparison to $H$. indica (NBAIIH38 strain). The study was conducted in Petri dish (diam. $9 \mathrm{~cm}$, depth $1.8 \mathrm{~cm}$ ), was filled with $20 \mathrm{~g}$ of sterilized soil and moisture was adjusted to $15 \%$ by adding water. Fresh leaf discs of individual host plant were placed in a Petri dish to feed insects. Each Petri dish was inoculated by each nematode species at 0, 25, 50, 100, $200 \mathrm{IJs}_{\text {larva }}{ }^{-1}$. After an hour, 4 individuals of $3^{\text {rd }}$ larval instar of each insect host species were released to each dish. Larval mortality was recorded 2 days after nematode inoculation, and nematode infection was confirmed by dissecting cadavers under a stereomicroscope. The whole experiment was repeated with 5 replicates.

\section{Evaluation of biocontrol potential against eggplant ash weevil}

In this experiment, biocontrol potential of Steinernema sp. (IIVR JNC01 strain) was tested against $2^{\text {nd }}$ instar grubs of $M$. subfasciatus in comparison to $H$. indica (NBAIIH38 strain). For this study, $30 \mathrm{ml}$ plastic cups (diam. $3.5 \mathrm{~cm}$, height $3.5 \mathrm{~cm}$, soil capacity 35 $\mathrm{g}$, total surface area $153.93 \mathrm{~cm}^{2}$, shape is round) were filled by $25 \mathrm{~g}$ of sterilized soil, and moisture was adjusted to $12 \%$. Potato pieces were added to each plastic cup to feed the grub. A single $2^{\text {nd }}$ instar grub of M. subfasciatus was placed in each cup. After $24 \mathrm{~h}$, grub was inoculated with each nematode species at 0 , 100,300 , and $500 \mathrm{IJs}_{\text {grub }^{-1}}$. Then cups were placed in incubator at $25 \pm 1{ }^{\circ} \mathrm{C}$. Each treatment had 20 replicates and grub mortality was assessed on daily basis up to 7 days. Cadavers were placed on White's traps and confirmed the death is due to EPNs by observing the nematode emergence from cadavers. The whole experiment was repeated with 20 replicates.

\section{Statistical analysis}

Before statistical analysis, percentage mortality data were normalized, using arcsine transformation. Analysis was undertaken on the transformed data. An ANOVA was conducted using PROC ANOVA (SAS version 9.3; SAS institute 2011, Cary, NC, USA). When ANOVA was significant, relevant means were compared to Tukey's significance test values at the $5 \%$ level of significance. 
Table 1 Details of soil samples collected from different habitats from Purvanchal and Bundelkhand Region of Uttar Pradesh, India

\begin{tabular}{|c|c|c|c|c|c|c|}
\hline District & $\begin{array}{l}\text { Location/ } \\
\text { village }\end{array}$ & $\begin{array}{l}\text { Total } \\
\text { samples }\end{array}$ & $\begin{array}{l}\text { Latitude and } \\
\text { Longitude }\end{array}$ & $\begin{array}{l}\text { EPN } \\
+/-\end{array}$ & $\begin{array}{l}\text { Soil } \\
\text { texture }\end{array}$ & $\begin{array}{l}\text { Vegetation/ } \\
\text { habitat }\end{array}$ \\
\hline \multirow[t]{3}{*}{ Varanasi } & $\begin{array}{l}\text { ICAR-Indian Institute of } \\
\text { Vegetable Research }\end{array}$ & 41 & $\begin{array}{l}25.182430 \\
82.877036\end{array}$ & + & Silt loam & $\begin{array}{l}\text { Basalla, Drum stick, Brinjal, Okra, Pointed gourd, Cowpea, Mango, } \\
\text { Alstonia scholaris, Saraca asoca, and Casuarina }\end{array}$ \\
\hline & Marahachh & 05 & $\begin{array}{l}25.191802 \\
82.893805\end{array}$ & - & $\begin{array}{l}\text { Clay } \\
\text { loam }\end{array}$ & Brinjal, Bottle gourd and Chilli \\
\hline & Jayapur & 10 & $\begin{array}{l}25.209640 \\
82.817686\end{array}$ & - & $\begin{array}{l}\text { Sandy } \\
\text { loam }\end{array}$ & Bottle gourd, Sponge gourd, and Cucumber Teak, and Guava \\
\hline \multirow[t]{3}{*}{ Mirzapur } & Jalalpur Mafi & 11 & $\begin{array}{l}25.163007 \\
82.923188\end{array}$ & - & $\begin{array}{l}\text { Sandy } \\
\text { clay } \\
\text { loam }\end{array}$ & Bottle gourd, Bitter gourd, and Cucumber \\
\hline & Adalpur & 10 & $\begin{array}{l}25.175110 \\
82.875772\end{array}$ & - & Silt loam & Mango, Gauva, and Lime \\
\hline & Araziline & 13 & $\begin{array}{l}25.180249 \\
82.888203\end{array}$ & - & Silt loam & Brinjal, Bottle gourd, and Chilli \\
\hline Deoria & Krishi Vigyan Kendra & 05 & $\begin{array}{l}26.314071 \\
84.001102\end{array}$ & - & $\begin{array}{l}\text { Sandy } \\
\text { loam }\end{array}$ & Amla and Mango \\
\hline Sonbhadra & Kushahi & 12 & $\begin{array}{l}24.767710 \\
83.008899\end{array}$ & - & $\begin{array}{l}\text { Clay } \\
\text { loam }\end{array}$ & Chilli, Brinjal, Bottle gourd, Teak, and Tamarind \\
\hline Jhansi & $\begin{array}{l}\text { ICAR-Central Agroforestry } \\
\text { Research Institute }\end{array}$ & 23 & $\begin{array}{l}25.505194 \\
78.543148\end{array}$ & + & $\begin{array}{l}\text { Sandy } \\
\text { loam }\end{array}$ & $\begin{array}{l}\text { Teak, Neem, Amla, Pearl Millet, Napier hybrid grass, Guinea Grass, } \\
\text { Black gram, Green gram, Pongemia, and Berseem }\end{array}$ \\
\hline Total & & 130 & & & & \\
\hline
\end{tabular}

Note: $+=$ EPNs recovered, $-=$ no EPNs recovered

\section{Results and discussion}

\section{Isolation, identification, and characterization of native}

\section{EPN strains}

Detailed information of EPN strains and the locations from where they were isolated is given in Table 1. Out of 130 soil samples collected, EPNs were recovered only from 3 samples (2.3\%). Among these 3 samples, 2 (Steinernema sp. IIVR JNC01 strain, Steinernema sp. IIVR JNC02 strain) belongs to Jhansi District of Bundelkhand Region and 1 (Steinernema sp. IIVR EPN03 strain) from Varanasi District of Purvanchal Region. EPN survey revealed that there is relatively low occurrence of EPNs in these regions of Uttar Pradesh. Similar to this study, previous studies also revealed a low occurrence of EPNs in western part of Uttar Pradesh (Istkhar and Chaubey 2017 and Devindrappa et al. 2019). The present study was conducted as a regional survey, which frequently has EPN with low recovery frequency value, contrary to rational sampling, which could maximize nematode isolation (Abd-Elgawad 2020). The other possible reasons for low occurrence of EPNs from collected soil samples might be influenced by climatic factors of particular region. Prevalence of long dry spell, low relative humidity, and high atmospheric temperature may suppress the abundance of EPNs in these regions. Previous studies revealed that temperature is one factor that regulates the temporal and spatial distribution of EPNs because these nematodes are highly sensitive to environmental extremes such as temperature and relative humidity (Gaugler 1981; Ehlers and Peters 1996 and Laznik and Trdan 2012).

Morphology and morphometric studies of different life stages (IJs, adults of $1^{\text {st }}$ and $2^{\text {nd }}$ generations) of 3 Steinernema IIVR strains isolated in this study revealed closer resemblance with S. siamkayai Stock, Somsook and Reid (Fig. 1). The morphometric analysis of S. siamkayai (IIVR JNC01 strain) was given in Table 2. Morphometric characteristics of S. siamkayai (IIVR JNC01 strain) were compared with originally described $S$. siamkayai (Stock et al. 1998). Morphometrically, body length of IJs of S. siamkayai (IIVR JNC01 strain) was comparatively longer than the original description 464 (452-472) vs 446 (398-495) $\mu \mathrm{m}$. Apart from this, distance from anterior end to nerve ring $78(70-86)$ vs $72(68-80) \mu \mathrm{m}$. The first generation female also showed difference in body length 4492 (38974921) vs 3937 (3161-5172) $\mu \mathrm{m}$, and body width 231.4 (181-273) vs 198 (170-280) $\mu \mathrm{m}$. Females of second generation also showed variation in body length 1867 (18121919) vs $1836(1410-2560) \mu \mathrm{m}$. Similarly, the $1^{\text {st }}$ and $2^{\text {nd }}$ generation males' body length also varied with original description. Nevertheless, most of the characters such as distance from anterior end to excretory pore, distance from anterior end to nerve ring, tail length, mucro length, a, b, c, SL, GL SW, GS, and D\% were not showed much differences with original description. A comparison of important morphometric parameters between S. siamkayai (IIVR JNC01 strain) and original description of S. siamkayai Stock, Somsook, and Reid is shown in Table 3. In addition, molecular characterization revealed that the 

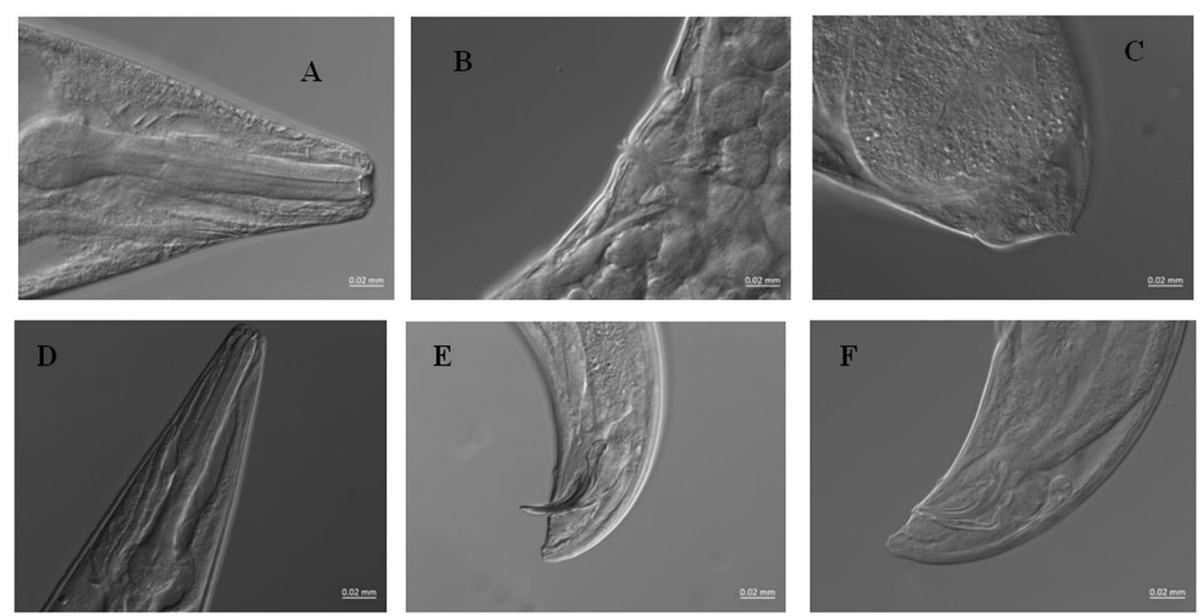

Fig. 1 LM photos of first generation female. a Anterior part with excretory pore. b Vulva with epiptygma. c Tail with mucro and first generation male. $\mathbf{d}$ Anterior part with excretory pore. e Spicule lateral view with mucro. $\mathbf{f}$ Gubernaculum lateral view

Table 2 Morphometrics of Steinernema siamkayai (IIVR JNC01 strain) (measurements are in $\mu \mathrm{m}$ and in the form of mean \pm SD (range)

\begin{tabular}{|c|c|c|c|c|c|}
\hline \multirow[t]{2}{*}{ Character } & \multirow{2}{*}{$\begin{array}{l}\text { Infective juveniles } \\
\left(\mid J^{\prime} s\right)(n=20)\end{array}$} & \multicolumn{2}{|l|}{ First generation } & \multicolumn{2}{|l|}{ Second generation } \\
\hline & & Females $(n=20)$ & Males $(n=20)$ & Females $(n=20)$ & Males $(n=20)$ \\
\hline Body length (L) & $\begin{array}{l}464 \pm 6.6 \\
(452-472)\end{array}$ & $\begin{array}{l}4492 \pm 264.8 \\
(3897-4921)\end{array}$ & $\begin{array}{l}1193 \pm 84.7 \\
(1098-1324)\end{array}$ & $\begin{array}{l}1867 \pm 37.6 \\
(1812-1919)\end{array}$ & $\begin{array}{l}855 \pm 44.4 \\
(784-906)\end{array}$ \\
\hline Greatest body width & $\begin{array}{l}20.8 \pm 1.3 \\
(18-23)\end{array}$ & $\begin{array}{l}231.4 \pm 22.1 \\
(181-273)\end{array}$ & $\begin{array}{l}142.1 \pm 10.5 \\
(102-152)\end{array}$ & $\begin{array}{l}109 \pm 10.3 \\
(85-124)\end{array}$ & $\begin{array}{l}65.4 \pm 9.9 \\
(48-78)\end{array}$ \\
\hline EP & $34.2 \pm 1.2(32-36)$ & $64.4 \pm 2.6(61-68)$ & $60.3 \pm 2.2(59-66)$ & $66.9 \pm 1.5(65.5-69)$ & $60.8 \pm 2.1(59-66)$ \\
\hline ES & $\begin{array}{l}101.1 \pm 8.9 \\
(83-112)\end{array}$ & $\begin{array}{l}177.2 \pm 14 \\
(149-196)\end{array}$ & $\begin{array}{l}138.3 \pm 4.2 \\
(132-145)\end{array}$ & $\begin{array}{l}153.6 \pm 6.4 \\
(142-164)\end{array}$ & $\begin{array}{l}123.4 \pm 6.5 \\
(110-131)\end{array}$ \\
\hline NR & $78.0 \pm 4.2(70-86)$ & $137 \pm 9.2(119-151)$ & $86.6 \pm 7.1(79-102)$ & $124 \pm 5.5(115-134)$ & $84.0 \pm 3.3(78-89)$ \\
\hline Tail length (TL) & $35.3 \pm 2.6(32-40)$ & $31 \pm 4.9(23-37)$ & $26.1 \pm 3.8(20-32)$ & $38.9 \pm 4.7(31-49)$ & $22.2 \pm 2.2(20-27)$ \\
\hline Body width at cloaca & - & - & $47.5 \pm 6.6(35-58)$ & - & $28.6 \pm 1.2(27-30)$ \\
\hline Spicule length & - & - & $77.7 \pm 1.2(76-79)$ & - & $59.7 \pm 2.5(55-63)$ \\
\hline Spicule width & - & - & $8.5 \pm 0.5(7.7-9.3)$ & - & $5.9 \pm 0.4(5.0-6.8)$ \\
\hline Gubernaculum length & - & - & $55.8 \pm 7.3(45-67)$ & - & $42.2 \pm 2.3(39-46)$ \\
\hline Gubernaculum width & - & - & $5.4 \pm 0.8(3.8-6.7)$ & - & $3.7 \pm 0.4(3.0-4.7)$ \\
\hline Mucro length & - & $7.9 \pm 1.4(5.2-10.4)$ & $3.1 \pm 0.3(2.6-3.7)$ & $4.4 \pm 1(3.2-6.2)$ & $2.8 \pm 0.5(2.2-3.8)$ \\
\hline$a$ & $22.4 \pm 1.5(19.9-26.1)$ & - & - & - & - \\
\hline$b$ & $4.6 \pm 0.4(4.2-5.5)$ & & - & - & - \\
\hline c & $13.2 \pm 0.9(11.4-14.3)$ & & - & - & - \\
\hline SW & - & - & $\begin{array}{l}1.67 \pm 0.2 \\
(1.36-2.17)\end{array}$ & & $\begin{array}{l}2.09 \pm 0.1 \\
(1.87-2.37)\end{array}$ \\
\hline GS & - & - & $0.72 \pm 0.1(0.57-0.88)$ & & $0.7 \pm 0.1(0.66-0.75)$ \\
\hline V\% & - & $48.7 \pm 1.0(47-50)$ & - & $53.4 \pm 2.0(50-56.5)$ & - \\
\hline $\left.\mathrm{D} \%\left\{(\mathrm{EP} / \mathrm{ES})^{*} 100\right)\right\}$ & $34.0 \pm 2.9(30-40)$ & - & $43.2 \pm 1.7(40-45)$ & - & $49.4 \pm 3.0(47-54)$ \\
\hline $\left.\mathrm{E} \%\left\{(\mathrm{EP} / \mathrm{TL})^{*} 100\right)\right\}$ & $\begin{array}{l}97.4 \pm 7.0 \\
(82-106)\end{array}$ & - & $\begin{array}{l}237.2 \pm 38.5 \\
(184.3-309)\end{array}$ & - & $\begin{array}{l}276.6 \pm 21.5 \\
(226-300)\end{array}$ \\
\hline
\end{tabular}

$E P$ distance from anterior end to excretory pore, NR distance from anterior end to nerve ring, ES distance from anterior end to end of pharynx/esophagus, $a$ body length/body width, $b$ body length/ES, $c$ body length/tail length, SW spicule length divided by anal body diameter, GS gubernaculum length divided by spicule length, $V \%$ distance from anterior end to end vulva as percentage of length 


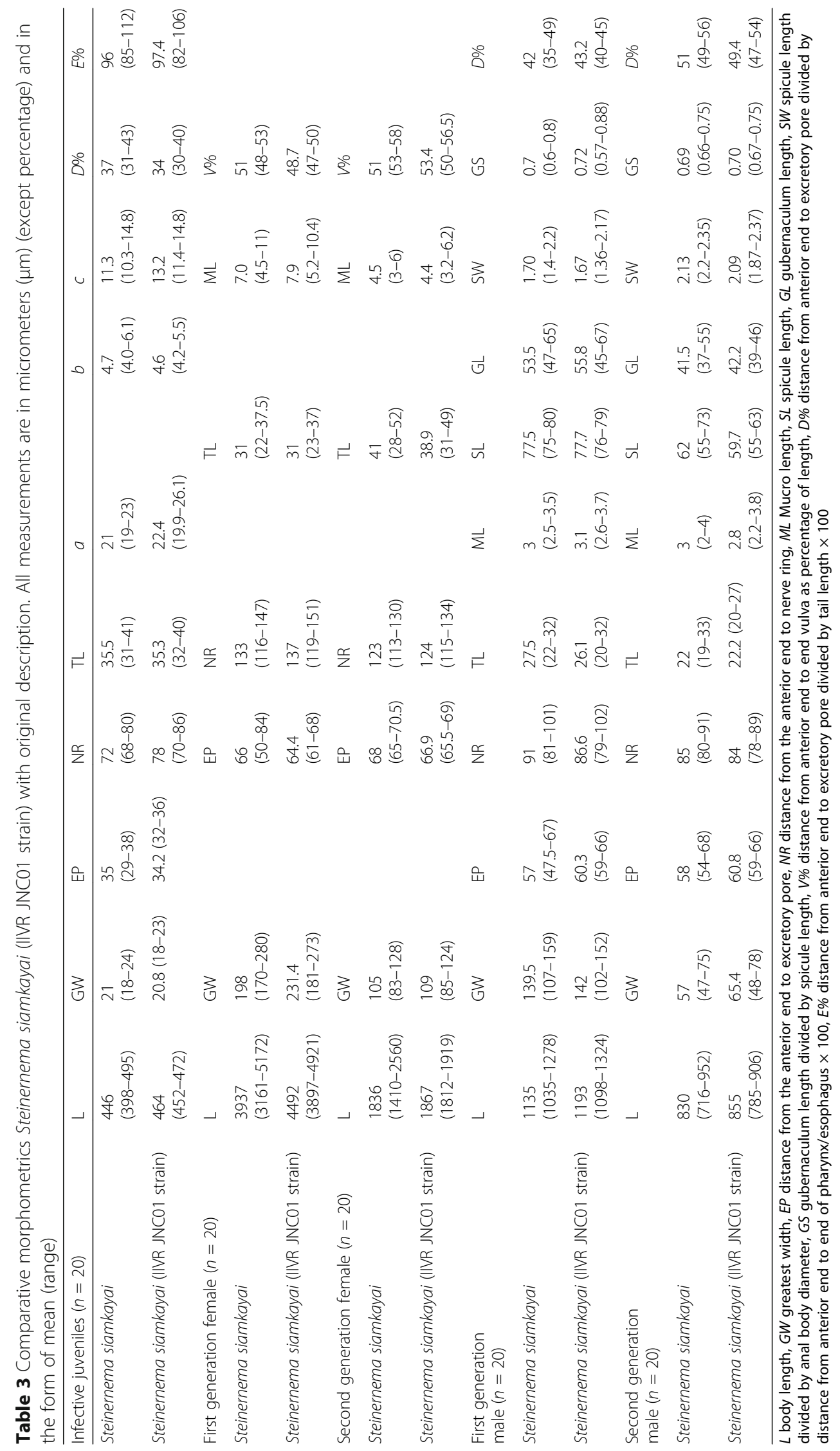


native EPN strains yielded $\sim 800$ bp fragment upon PCR amplication with the ITS primers. Ribosomal DNA (ITSrDNA region of EPNs) sequences generated for the strains were aligned and matched with available sequences in NCBI GenBank. The BLAST search analysis of DNA sequence of native EPN strains showed > 99\% matches to authenticated reference sequence of $S$. siamkayai. Based on the morphological examinations and information supported by molecular tool, Steinernema strains isolated in this study were identified as S. siamkayai (IIVR JNC01 strain) (GenBank accession no. MH208855), S. siamkayai (IIVR JNC02 strain) (GenBank accession no. MH208856), and S. siamkayai (IIVR EPN03 strain) (GenBank accession no. MG976754). Phylogenetic relationship between all the three IIVR strains of $S$. siamkayai and previously identified S. siamkayai and other Steinernema species are presented in Fig. 2.

\section{Biocontrol potential of EPNs against lepidopteran pests of} vegetable crops

Laboratory bioassays were designed to evaluate the biocontrol potential of $S$. siamkayai (IIVR JNC01 strain) in comparison to commercially available $H$. indica (NBAIIH38 strain) against $3^{\text {rd }}$ instar larvae of S. litura, S. obliqua, and S. recurvalis. Bioassays data revealed that when $H$. indica (NBAIIH38 strain) inoculated at rate of $200 \mathrm{IJs}_{\mathrm{s}} \mathrm{arva}^{-1}$ caused $100 \%$ mortality in $3^{\text {rd }}$ instar of all the 3 insect host species tested in this study. Similarly, S. siamkayai (IIVR JNC01 strain) also caused $100 \%$ mortality in $3^{\text {rd }}$ instar of S. litura and S. obliqua whereas $85 \%$ mortality in $3^{\text {rd }}$ instar of $S$. recurvalis (Fig. $3 \mathrm{a}-\mathrm{c}$ ). Analysis of variance revealed that, among the nematode species, irrespective of IJ concentrations, $H$. indica (NBAIIH38 strain) caused greater mortality only in $S$. recurvalis compared to $S$. siamkayai (IIVR JNC01 strain) $(F=13.86, \mathrm{df}=1,90$, $P=0.0003)$. However, there was non-significant difference in mortality caused by both EPN species on $3^{\text {rd }}$ instar larvae of $S$. litura $(F=2.82, \mathrm{df}=1,90, P=$ $0.09)$ and $S$. obliqua $(F=1.69, \mathrm{df}=1,90, P=0.20)$. The calculated $\mathrm{LC}_{50}$ and $\mathrm{LC}_{90}$ values for $S$. siamkayai (IIVR JNC01 strain) and $H$. indica (NBAIIH38 strain) on S. recurvalis, S. litura, and S. obliqua are shown in Table 4. Adiroubane et al. (2010) found that $S$. siamkayai isolated from Karaikal Region of

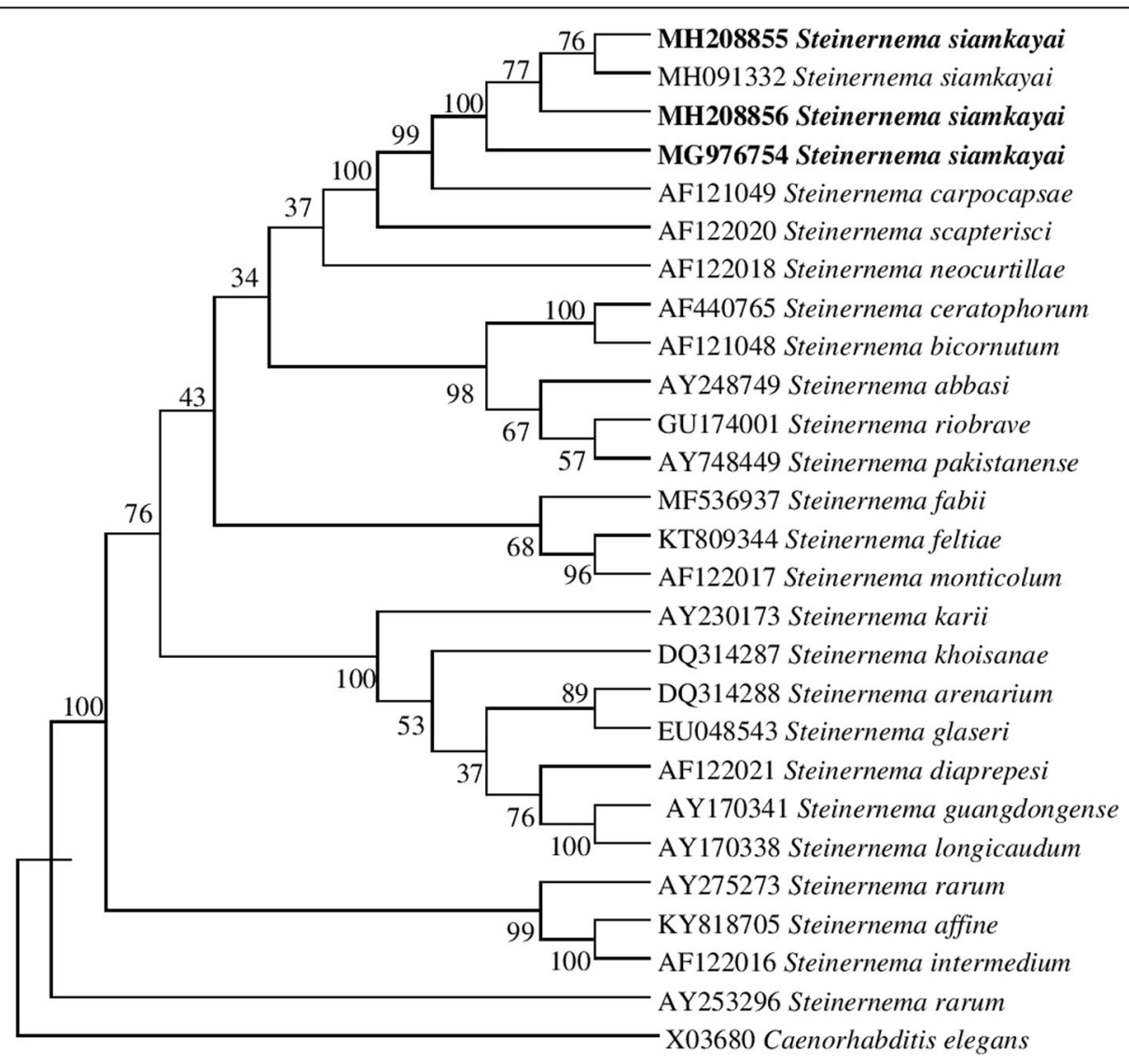

Fig. 2 Phylogenetic relationships of Steinernema siamkayai IIVR strains with other Steinernema spp. based on ITS-rDNA regions 

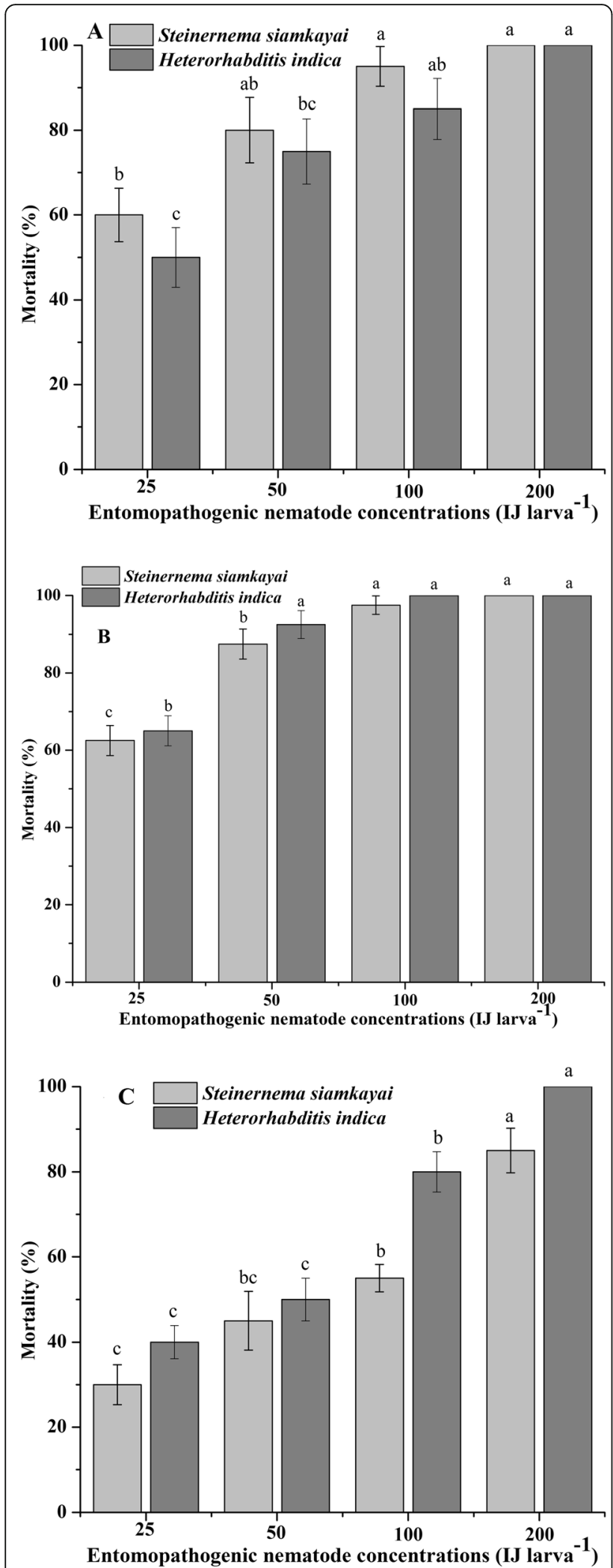

Fig. 3 Percent mean mortality of $3^{\text {rd }}$ instar larvae of a Spodoptera litura, b Spilosoma obliqua, c Spoladea recurvalis at different concentrations of entomopathogenic nematodes, Steinernema siamkayai (IIVR JNC01 strain), and Heterorhabditis indica (NBAllH38 strain) at 2 days after treatment. Different letters on the top of error bars indicate statistically different values for different nematode concentrations at $(P<0.05)$ using Tukey's test. Bars $=$ standard error $(n=40)$

Puducherry, India, had greater biocontrol potential against larval stages and pre-pupae of S. litura. Steinernema longicaudum X-7, Steinernema sp. 64-2, four isolates of $S$. carpocapsae, and 2 isolates of $H$. indica caused $>90 \%$ mortality in $2^{\text {nd }}, 3^{\text {rd }}$, and $4^{\text {th }}$ larval instars of S. litura (Yan et al. 2019). Similarly, in the present study, it is also evidenced that S. siamkayai (IIVR JNC01 strain) had greater biocontrol potential against $3^{\text {rd }}$ larval instar of S. litura, S. obliqua, and $S$. recurvalis, and the efficacy was quite comparable to commercially available $H$. indica (NBAIIH38 strain). In addition, present findings provide the first insight into the biocontrol potential of $S$. siamkayai (IIVR JNC01 strain) and $H$. indica (NBAIIH38 strain) against $3^{\text {rd }}$ instar larvae of $S$. recurvalis, the major pest of leafy vegetables, particularly on amaranthus grown in Purvanchal and Bundelkhand regions of Uttar Pradesh.

Biocontrol potential of EPNs against eggplant ash weevil This assay revealed that both EPN species were able to kill $2^{\text {nd }}$ larval instar of grubs of $M$. subfasciatus. When a concentration of $500 \mathrm{IJs}_{\mathrm{srub}}{ }^{-1}$ was applied, the greatest mortality of $2^{\text {nd }}$ larval instar of grubs was observed for $H$. indica (NBAIIH38 strain) (100\%) and S. siamkayai (IIVR JNC01 strain) (92.5\%) (Fig. 4). Analysis of variance showed that biocontrol potential of S. siamkayai (IIVR JNC01 strain) was comparable with $H$. indica (NBAIIH38 strain) against $2^{\text {nd }}$ larval instar of grubs of $M$. subfasciatus. The calculated $\mathrm{LC}_{50}$ and $\mathrm{LC}_{90}$ values for S. siamkayai (IIVR JNC01 strain) and $H$. indica (NBAIIH38 strain) on $2^{\text {nd }}$ larval instar of grubs were shown in Table 4. Similarly, Gowda et al. (2016) reported that $S$. carpocapsae and $H$. indica had greater biocontrol potential against $3^{\text {rd }}$ instar larvae and pre-pupae of $M$. subfaciatus. In another study, Nagesh et al. (2016) demonstrated greater biocontrol potential of $H$. bacteriophora NBAIIHb105, $H$. indica NBAIIHi101, $H$. indica NBAIIHiMah, $S$. abbasi NBAIISa01, $S$. abbasi NBAIISa04, S. carpocapsae NBAIISc04, and S. glaseri NBAIISg01 against $M$. subfasciatus. Inclusively, earlier and present studies indicated that EPNs are the best candidates for the management of $M$. subfaciatus. 
Table 4 The lethal concentration ( $\mathrm{LC}_{50}$ and $\mathrm{LC}_{90}$ ) of Steinernema siamkayai (IIVR JNC01 strain) and Heterorhabditis indica (NBAIlH38 strain) against lepidopteran pests at 2 days after treatment and eggplant ash weevil (Myllocerus subfaciatus Guerin.) at 7 days after treatment

\begin{tabular}{|c|c|c|c|c|c|c|c|c|}
\hline $\begin{array}{l}\text { Lepidopteran insect } \\
\text { pests }\end{array}$ & Entomopathogenic nematode species & $\mathrm{LC}_{50}$ & $\begin{array}{l}95 \% \text { Fiducial } \\
\text { limits }\end{array}$ & $\mathrm{LC}_{90}$ & $\begin{array}{l}95 \% \text { Fiducial } \\
\text { limits }\end{array}$ & $\begin{array}{l}\text { Slope } \pm \\
\text { SE }\end{array}$ & $x^{2}$ & $\begin{array}{l}P(< \\
0.05)\end{array}$ \\
\hline \multirow[t]{2}{*}{ Spoladea recurvalis } & $\begin{array}{l}\text { Steinernema siamkayai (IIVR JNC01 } \\
\text { strain) }\end{array}$ & 60 & $42-81$ & 385 & $221-1300$ & $\begin{array}{l}1.58 \pm \\
0.32\end{array}$ & 24.15 & $<0.0001$ \\
\hline & Heterorhabditis indica (NBAllH38 strain) & 39 & $24-53$ & 205 & $116-1244$ & $\begin{array}{l}1.78 \pm \\
0.49\end{array}$ & 12.92 & 0.0003 \\
\hline \multirow[t]{2}{*}{ Spodoptera litura } & $\begin{array}{l}\text { Steinernema siamkayai (IIVR JNCO1 } \\
\text { strain) }\end{array}$ & 20 & $11-28$ & 68 & $52-109$ & $\begin{array}{l}2.46 \pm \\
0.53\end{array}$ & 21.59 & $<0.0001$ \\
\hline & Heterorhabditis indica (NBAllH38 strain) & 27 & $16-35$ & 103 & $77-178$ & $\begin{array}{l}2.19 \pm \\
0.42\end{array}$ & 26.97 & $<0.0001$ \\
\hline \multirow[t]{2}{*}{ Spilosoma obliqua } & $\begin{array}{l}\text { Steinernema siamkayai (IIVR JNCO1 } \\
\text { strain) }\end{array}$ & 19 & $10-26$ & 55 & $43-84$ & $\begin{array}{l}2.83 \pm \\
0.65\end{array}$ & 18.79 & $<0.0001$ \\
\hline & Heterorhabditis indica (NBAllH38 strain) & 20 & $11-25$ & 43 & $35-65$ & $\begin{array}{l}3.83 \pm \\
1.00\end{array}$ & 14.73 & $<0.0001$ \\
\hline \multirow[t]{2}{*}{ Myllocerus subfaciatus } & $\begin{array}{l}\text { Steinernema siamkayai (IIVR JNC01 } \\
\text { strain) }\end{array}$ & 105.51 & $49.9-150.3$ & 519.74 & $369.8-1482$ & $\begin{array}{l}1.85 \pm \\
0.44\end{array}$ & 12.91 & 0.0003 \\
\hline & Heterorhabditis indica (NBAllH38 strain) & 95.04 & - & 335.9 & - & $\begin{array}{l}2.33 \pm \\
1.05\end{array}$ & 03.67 & 0.055 \\
\hline
\end{tabular}

\section{Conclusion}

Search and identification of native EPN species/ strains, adapted to local agro-climatic conditions, as a biocontrol potential agent against major insect pests, serve as a critical component in developing integrated pest management program of a particular pest. In this study, S. siamkayai (IIVR JNC01 strain) and H. indica
(NBAIIH38 strain) showed greater biocontrol potential against $S$. recurvalis, S. litura, S. obliqua, and $M$. subfaciatus. Moreover, high virulence of EPNs attained under laboratory conditions cannot be generalized for the field efficacy. Further evaluations of their biocontrol potentials should be tested under poly greenhouse and field conditions.

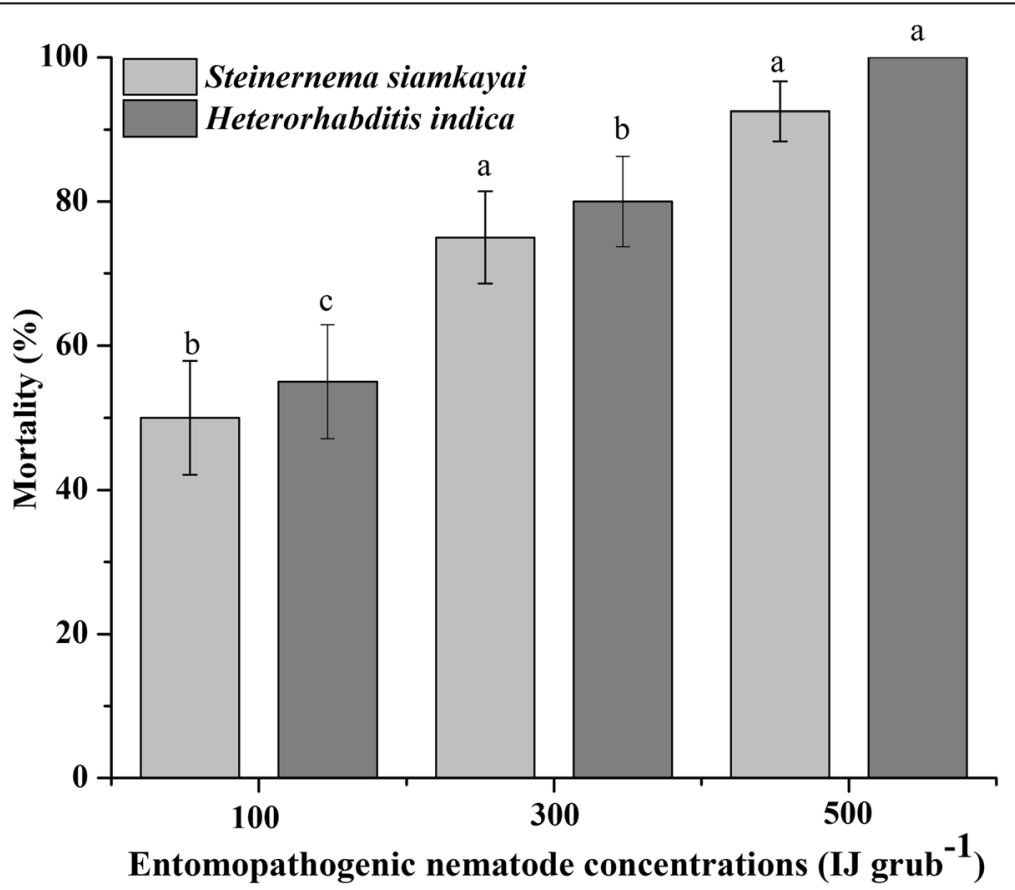

Fig. 4 Mortality (mean\% \pm SE) of $2^{\text {nd }}$ instar grub of Myllocerus subfaciatus Guerin at different concentrations of entomopathogenic nematodes, Steinernema siamkayai (IIVR JNC01 strain), and Heterorhabditis indica (NBAllH38 strain) at 7 days after treatment. Different letters on the top of error bars indicate statistically different values for different nematode concentrations at $(P<0.05)$ using Tukey's test. Bars $=\operatorname{standard}$ error $(n=40)$ 


\section{Abbreviations}

EPNs: Entomopathogenic nematodes; IJs: Infective juveniles; ICAR: Indian Council of Agricultural Research; IIVR: Indian Institute of Vegetable Research; NBAIR: National Bureau of Agricultural Insect Resources; ANOVA: Analysis of variance; TAF: Triethanolamine formalin; LC: Lethal concentration; ITS: Internal transcribed spacer; BLAST: Basic Local Alignment Search Tool; NCBI: National Center for Biotechnology Information; PCR: Polymerase chain reaction

\section{Acknowledgements}

The authors are grateful to the Director, ICAR-Indian Institute of Vegetable Research, Varanasi, and the Director, ICAR-National Bureau of Agricultural Insect Resources, Bengaluru, India, for the facilities provided for conducting this study.

\section{Authors' contributions}

MTG, JP, and ABR designed the research. MTG, PAD, and VK collected soil samples. VR molecularly characterized the EPNs. JP studied the morphological characters of EPNs. MTG JP, JH, VK, and PAD conducted the experiments. MTG and JP analyzed the data. MTG, JP, JH, ABR, and JS wrote the manuscript. All authors read and approved the final manuscript.

\section{Funding}

The authors are grateful to the Indian Council of Agricultural Research, New Delhi, India, for funding.

\section{Availability of data and materials}

The datasets used and/or analyzed during the current study are available from the corresponding author on reasonable request.

\section{Ethics approval and consent to participate}

All experimental works were approved by ICAR-Indian Institute of Vegetable Research, Varanasi and ICAR-National Bureau of Agricultural Insect Resources, Bengaluru, India.

\section{Consent for publication}

The agreement of publication was taken, and as a corresponding author, I confirm that.

\section{Competing interests}

The authors declare that they have no competing interests.

\section{Author details}

'ICAR-Indian Institute of Vegetable Research, Varanasi 221305, India.

${ }^{2}$ ICAR-National Bureau of Agricultural Insect Resources, Bengaluru 560024, India.

Received: 21 April 2020 Accepted: 23 June 2020

Published online: 13 July 2020

\section{References}

Abd-Elgawad MMM (2020) Can rational sampling maximize isolation and fix distribution measure of entomopathogenic nematodes?. Nematology 22, https://doi.org/10.1163/15685411-00003350

Adiroubane D, Tamilselvi R, Ramesh V (2010) Efficacy of Steinernema siamkayai against certain crop pests. J Biopesticides 3:180-185

Bohinc T, Vucajnk F, Trdan S (2019) The efficacy of environmentally acceptable products for the control of major potato pests and diseases. Zemdirbyste 106:135-142

Ciche TA, Darby C, Ehlers RU, Forst S, Goodrich-blair H (2006) Dangerous liasons: The symbiosis of entomopathogenic nematodes and bacteria. Biol Control 38:22-46

Devindrappa SMB, Singh B, Kumar K (2019) Identification and parasitic potential of Steinernema siamkayai against soil-dwelling stage of Helicoverpa armigera (Hub.) under laboratory condition. J Entomol Zool Stud 7:493-498

Ebssa L, Koppenhofer AM (2011) Efficacy and persistence of entomopathogenic nematodes for black cutworm control in turf grass. Biocontrol Sci Technol 21: 779-796

Ehlers RU, Peters A (1996) Entomopathogenic nematodes in biological control: feasibility, perspectives and possible risks. In: Hokkanen HMT, Lynch JM (eds) Biological control: benefits and risks. Cambridge University Press, Cambridge
Gaugler R (1981) Biological control potential of neoaplectanid nematodes. J Nematol 13:241-249

Gaugler R (1988) Ecological considerations in the biological control of soilinhabiting insects with entomopathogenic nematodes. Agr Ecosyst Environ 24:351-360

Gowda MT, Patil J, Devindrappa M, Vijayakumar R, Abraham V (2016) Entomopathogenic nematodes: a potential biocontrol agent against eggplant ash weevil Myllocerus subfasciatus Guerin (Coleoptera: Curculionidae). Nematology 18:743-750

Ishibashi N, Choi DR (1991) Biological control of soil pests by mixed applications of entomopathogenic and fungivorous nematodes. J Nematol 23:175-181

Istkhar CAK (2017) Impact of soil dwelling entomopathogenic nematodes, recovered from the soil of Uttar Pradesh (India), on cotton bollworm Helicoverpa armigera (Hubner) (Lepidoptera: Noctuidae). Appl Biol Res 19:63-70

Joyce SA, Reid A, Driver F, Curran J (1994) Application of polymerase chain reaction $(P C R)$ methods to the identification of entomopathogenic nematodes. In: Burnell AM, Ehlers RU, Masson JP, (eds). COST 812 Biotechnology: Genetics of Entomopathogenic Nematode-bacterium complexes, proceedings of symposium and workshop. St Patrick's College, Maynooth, Co. Kildare, Ireland. DG XII, Luxembourg: European Commission, pp. 178-187.

Kaya HK, Gaugler R (1993) Entomopathogenic nematodes. Annu Rev Entomol 38: $181-206$

Kaya HK, Stock SP (1997) Techniques in insect nematology. In: Lawrence AL (ed) Manual of 12 techniques in insect pathology. Academic Press, Wapato

Kumar S, Stecher G, Tamura K (2016) MEGA7: Molecular evolutionary genetics analysis version 7.0 for bigger datasets. Mol Bio Evol 33:1870-1874

Laznik Z, Trdan S (2012) Entomopathogenic nematodes (Nematoda: Rhabditida) in Slovenia: from Tabula Rasa to implementation into crop production systems. In: Perveen F (ed) Insecticides - advances in integrated pest management. In Tech, Rijeka, Licko-Senjska, Croatia, pp. 627-656.

Laznik Z, Znidarcic D, Trdan S (2011) Control of Trialeurodes vaporariorum (Westwood) adults on glasshouse-grown cucumbers in four different growth substrates: an efficacy comparison of foliar application of Steinernema feltiae (Filipjev) and spraying with thiamethoxamn. Turk J Agric For 35:631-640

Nagesh M, Krishna Kumar NK, Shylesha AN, Javeed S, Thippeswamy R (2016) Comparative virulence of strains of entomopathogenic nematodes for management of eggplant grey weevil, Myllocerus subfasciatus Guerin (Coleoptera: Curculionidae). Indian J Exp Biol 54:835-842

Noosidum A, Hodson AK, Lewis EE, Chandrapatya A (2010) Characterization of new entomopathogenic nematodes from Thailand: foraging behavior and virulence to the greater wax moth, Galleria mellonella L. (Lepidoptera: Pyralidae). J Nematol 42:281-291

Park SH, Yu YS, Park JS, Choo HY, Bae SD, Nam MH (2001) Biological control of tobacco cutworm, Spodoptera litura fabricius with entomopathogenic nematodes. Biotechnol Bioproc E 6:139-143

Patil J, Varshney R, Rangeshwaran R, Ramanujam B, Suby SB (2020) Management of fall army worm through biopesticides. In: Ansari MA, Jat SL, Saha S, Babu S, Yadav GS, Das A, Baishya LK, Singh R, Tasung A, Sharma SK, Bomit L, Suby SB, Sekhar JC, Prakash N, Rakshit S (eds) Highlighted extension achievement of Fall armyworm awareness campaign in North East Indian hills. ICAR Research Complex for NEH Region, Meghalaya, India and Indian Institute of Maize Research, PAU Campus, Ludhiana, Punjab, India, p 19

Pelczar MJ Jr, Reid RD (1972) Microbiology. McGraw Hill, New York

Poinar GO Jr (1990) Taxonomy and biology of Steinernematidae and Heterorhabditidae. In: Gaugler R, Kaya HK (eds) Entomopathogenic nematodes in biological control. CRC Press, Boca Raton, pp 23-61

SAS Institute (2011) SAS version 9.3 system options: reference, $2^{\text {nd }}$ edn. SAS Institute, Cary

Seinhorst JW (1959) A rapid method for the transfer of nematodes from fixative to anhydrous glycerin. Nematologica 4:67-69

Somvanshi VS, Ganguly S, Paul AVN (2006) Field efficacy of the entomopathogenic nematode Steinernema thermophilum Ganguly and Singh (Rhabditida: Steinernematidae) against diamondback moth (Plutella xylostella L.) infesting cabbage. Biol Control 37:9-15

Stock SP, Somsook V, Reid AP (1998) Steinernema siamkayai n. sp. (Rhabditida): Steinernematidae), an entomopathogenic nematode from Thailand. Syst Parasitol 41: 105-113.

Trdan S, Znidarcic D, Vidrih M (2007) Control of Frankliniella occidentalis on greenhouse-grown cucumbers: an efficacy comparison of foliar application of Steinernema feltiae and spraying with abamectin. Russ J Nematol 15:25-34 
White GF (1927) A method for obtaining infective nematode larvae from cultures. Science 66:302-303

Yan X, Arain MS, Lin Y, Gu X, Zhang L, Li J, Han R (2019) Efficacy of entomopathogenic nematodes against the tobacco cutworm, Spodoptera litura (Lepidoptera: Noctuidae). J Econ Entomol 113:64-72

Yuksel E, Canhilal R (2019) Isolation, identification, and pathogenicity of entomopathogenic nematodes occurring in Cappadocia Region, Central Turkey. Egypt J Biol Pest Co 29: 40. https://doi.org/10.1186/s41938-019-0141-9

\section{Publisher's Note}

Springer Nature remains neutral with regard to jurisdictional claims in published maps and institutional affiliations.

\section{Submit your manuscript to a SpringerOpen ${ }^{\mathcal{O}}$ journal and benefit from:}

- Convenient online submission

- Rigorous peer review

- Open access: articles freely available online

- High visibility within the field

- Retaining the copyright to your article

Submit your next manuscript at $\boldsymbol{\nabla}$ springeropen.com 